\title{
Identification by Microscopy of a Natural Hybrid between Portuguese Digitalis Species
}

\author{
J. Silva, E. T. Gomes, R. Serrano, and O. Silva
}

iMed.UL, Faculty of Pharmacy, University of Lisbon, Av. Prof. Gama Pinto, 1649-003 Lisboa, Portugal

Digitalis purpurea L. and Digitalis thapsi L. (Iberian endemism) are two well known Portuguese species that contain cardiac glycosides [1]. Last year we found some specimens in the Northeast region of Portugal that appeared to us to be natural hybrids between $D$. purpurea and D. thapsi. In consequence, morphological, genetic and chemical experimental work was performed, involving a minimum of 30 samples of each plant species collected in this geographic area. Preliminary results of this work have been published $[2,3,4]$.

Here we present a summary of all specific microscopic characteristics we found that allow the identification of the natural hybrid (D. thapsi x D. purpurea) and its consequent distinction from the origin species.

Conventional light microscopy (LM) and scanning electron microscopy (SEM) were the techniques used. Observations were made on transverse sections of the lamina and midrib and also in the lower and upper epidermises of each sample. Qualitative and quantitative data were analysed.

The principal results obtained are shown in Figures 1-3 and summarized in Table 1.

Hybrid specimens can be identified by the presence of:

- midrib (pronounced) with convex form on the lower surface of the leaf (Figure 1A); dorsiventral mesophyll with palisade parenchyma constituted by 2 cell layers and a thin spongy parenchyma (Figure 1B);

- upper epidermis with irregularly shaped cells, striated cuticle and few anomocytic stomata (Figure 2A, 2B); lower epidermis containing epidermal cells with a smooth cuticle (Figure 2C, 2D) and sinuous anticlinal walls and numerous anomocytic stomata with 4-6 subsidiary cells;

- glandular trichomes (abundant) - long with a uniseriate stalk (2-5 cells) and unicellular head (Figure 3A-3D); or short with a unicellular stalk and bicellular head (Figure 3E); or short with a unicellular stalk and unicellular head $(3 \mathrm{~F})$;

- non-glandular trichomes (few) multicellular, uniseriate, 1-5 cells, with smooth walls and narrow lumen (Figure 3G).

On the basis of the identified micromorphological characters we confirm the occurrence of natural hybridization between $D$. thapsi and $D$. purpurea in the Northeast region of Portugal.

References

1. Serrano et al., Microscopy: Science, Technology, Applications and Education, Microscopy Book Series No. 4, Ed. by A. Méndez-Vilas and J. Díaz Formatex 1: 182-190, 2010

2. Serrano et al., Book of Abstracts of International Congress on Natural Products Research. Phoenix (Arizona), USA, p. 482, 2004

3. Serrano et al., Book of Abstracts of Congress of the Portuguese Society for Microscopy. Braga, Portugal, p. 71, 2006

4. Frazão et al., Planta Medica 74 (9): 1135, 2008 

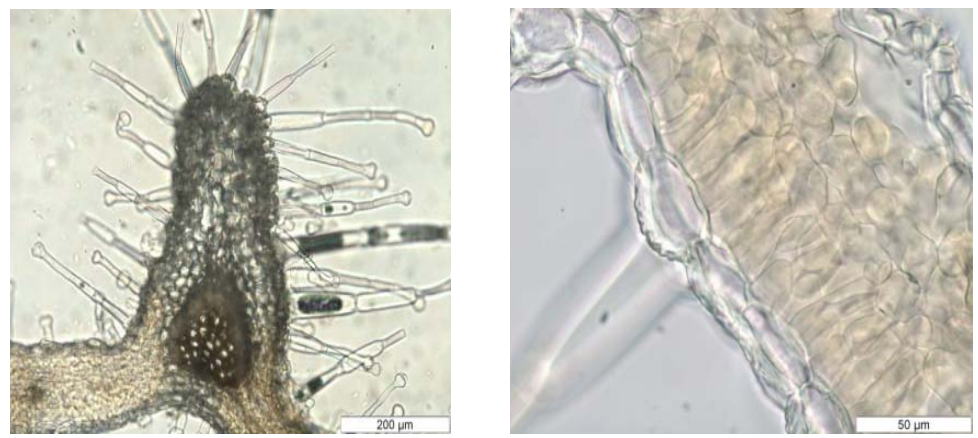

Figure 1. Leaf transverse section. (A) midrib (LM). (B) mesophyll with palisade parenchyma (b1) and spongy parenchyma (b2) (LM).
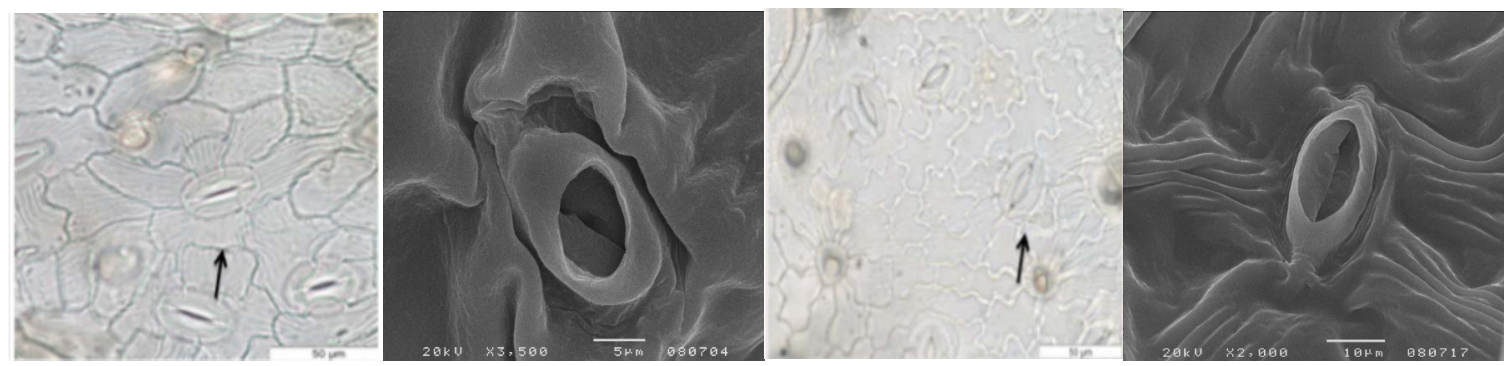

Figure 2. Surface view of the upper epidermis (two images on the left) with anomocytic stomata (arrow) (LM and SEM); surface view of the lower epidermis (two images on the right) with anomocytic stomata (arrow) (LM and SEM).
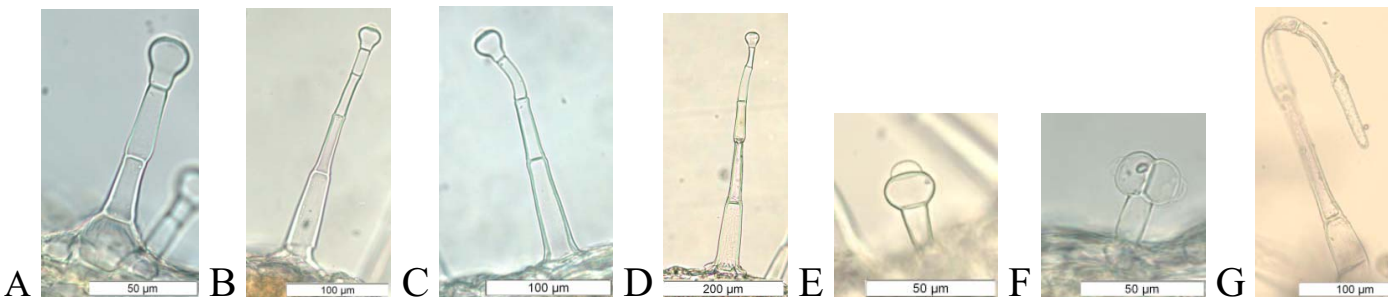

Figure 3. Trichomes: Glandular (A-F) (LM) and non-glandular (G) (LM).

Table 1. Principal distinctive microscopic features.

\begin{tabular}{|l|l|l|l|}
\hline & $\begin{array}{l}\text { D. purpurea } \\
\text { mean (standard deviation) }\end{array}$ & $\begin{array}{l}\text { D. thapsi } \\
\text { mean (standard deviation) }\end{array}$ & $\begin{array}{l}\text { Hybrid } \\
\text { mean (standard deviation) }\end{array}$ \\
\hline $\begin{array}{l}\text { Lower cuticle } \\
\text { aspect and } \\
\text { thickness* }\end{array}$ & smooth; $2,79(0,33)$ & striated; $8,74(0,64)$ & striated; 8,62 $(0,96)$ \\
\hline $\begin{array}{l}\text { Upper cuticle aspect } \\
\text { and thickness* }\end{array}$ & smooth; 3,28 $(0,33)$ & striated; $7,15(1,70)$ & striated; 7,80 $(0,93)$ \\
\hline $\begin{array}{l}\text { Length / width } \\
\text { stomata ratio }\end{array}$ & anomocytic; $1,56(6,05)$ & anomocytic; $1,39(4,16)$ & anomocytic; $1,21(2,39)$ \\
\hline $\begin{array}{l}\text { Total mesophyll } \\
\text { thickness* }\end{array}$ & $109,69(7,86)$ & $282,60(60,30)$ & $105,16(3,24)$ \\
\hline $\begin{array}{l}\text { Palisade } \\
\text { parenchyma, cell } \\
\text { layers and } \\
\text { thickness* }\end{array}$ & 1 cell layer; $41,95(5,50)$ & $\begin{array}{l}3 \text { cell layers; } 106,02 \\
(45,85)\end{array}$ & 2 cell layers; 41,24 $(1,24)$ \\
\hline $\begin{array}{l}\text { Spongy } \\
\text { parenchyma, cell } \\
\text { layers and } \\
\text { thickness* }\end{array}$ & $\begin{array}{l}3-4 \text { cell layers; } 67,75 \\
(9,53)\end{array}$ & $\begin{array}{l}4-5 \text { cell layers; } 110,73 \\
(58,04)\end{array}$ & $\begin{array}{l}3-4 \text { cell layers; } 58,42 \\
(2,93)\end{array}$ \\
\hline
\end{tabular}

$* \mu \mathrm{m}$ 